\title{
Isolation, characterization and phylogenetic analysis of endophytic bacteria in rice plant cultivated on soil of Phu Yen province, Vietnam
}

\author{
Van Thi Phuong Nhu ${ }^{1, ~}$, Cao Ngoc Diep ${ }^{2}$ \\ ${ }^{1}$ Dept. Biology, Phu Yen University, Phu Yen Province, Vietnam \\ ${ }^{2}$ Dept. Microbiology Biotechnology, Biotechnology R\&D Institute, Can Tho University, Can Tho City, Vietnam
}

Email address:

vanphuongnhu@gmail.com (V. T. P. Nhu),cndiep@ctu.edu.vn (C. N. Diep)

\section{To cite this article:}

Van Thi Phuong Nhu, Cao Ngoc Diep. Isolation, Charcaterization and Phylogenetic Analysis of Endophytic Bacteria in Rice Plant Cultivated on Soil of Phu Yen Province, Vietnam. American Journal of Life Sciences. Vol. 2, No. 3, 2014, pp. 117-127.

doi: 10.11648/j.ajls.20140203.11

\begin{abstract}
Endophytic bacterial diversity in Rice plant cultivated on soil of Phu Yen province, Vietnam was studied. Rice plant samples were taken in eight sites (districts) of Phu Yen provinces of this region. Endophytic bacteria were isolated in three kinds of medium (LGI, NFb, RMR) together with 16S rRNA gene fragments amplified from DNA using eubacterial universal primers (p515FPL and p13B). A total of 561 isolates were isolated on three media and all of them have ability of nitrogen fixation and phosphate solubilization together with IAA biosynthesis but there were 73 isolates having the best characteristics and they were identified as rice endophytes and nif $\mathrm{H}$ gene. The sequences from selected endophytic bacteria (73 isolates) showed high degrees of similarity to those of the GenBank references strains (between $97 \%$ and $100 \%$ ). From 73 isolates, 23 isolates belonged to Bacillus (31.54\%), 44 isolates were Proteobacteria (60.24\%), while 6 isolates were Bacteroides (8.22\%). Based on Pi value (nucleotide diversity), Bacteroides group had the highest theta values in comparison of three groups and Theta values (per sequence) from S of SNP for DNA polymorphism were calculated for each group and Bacteroides group had the highest values in comparison of three group. From these results showed that thirteen strains (Bacillus megaterium TANa5, Bacillus methylotrophicus TAN17, Bacillus megaterium TALa14, Pseudomonas putida TAL1, Bacillus subtilis TAL4, Burkholderia kururiensis TAL22, Azospirillum amazonense SHL70, Bacillus subtilis DXL 136, Burkholderia kururiensis PHL87, Burkholderia vietnamiensis PHL103, Bacillus megaterium PHL105, Bacillus megaterium DHL154 and Bacillus subtilis SHIM60) revealed promising candidates with multiple beneficial characteristics and they have the potential for application as inoculants or bio-fertilizer adapted to poor soils and high-yielding rice because they are not only famous strains but also are safety strains for agricultural sustainable.
\end{abstract}

Keywords: 16S rRNA Gene Sequence, Endophytic Bacteria, High-Yielding Rice, Phu Yen Province, Rice Growth Promoting

\section{Introduction}

Rice (Oryza sativa L.) is the most important cereal crop in the world, and the main dietary component of $20 \%$ of the world's population [1][2]; feeding more than $50 \%$ of the world's population [3]. In the next three decades, the world will need to produce about $60 \%$ more rice than today's global production to feed the extra billion people [4]. Increases in the demand for rice, as a result of an increase in population, creates the need to improve rice productivity and one of the most important factors for high yields of rice production are chemicals fertilizers and pesticides, which may cause environmental pollution and negatively influence human health.

Endophytic bacteria are microorganisms that live in plant tissues and they may be responsible for the supply of biologically fixed nitrogen to their host plant [5]. Endophytes also promote plant growth by a number of similar mechanisms as phosphate solubilization activity [6], indole acetic acid production [7] and the production of a siderophores [8].

Phu Yen province locates in Central Vietnam and it has 
the biggest rice production area $(56,913 \mathrm{ha})$ in the provinces of Central Vietnam. Local farmers applied many kinds of chemical fertilizer, especially inorganic nitrogen fertilizer, in the rice production and this leads high production cost but low income. In order to make rice cultivation sustainable and less dependent on chemical nitrogen fertilizer, it needs to be found the proportion of plant promoting bacteria, which are bacterial endophytes. The aims of this study were (i) isolation of rice endophytic bacteria, (ii) studying characteristic such as nitrogen fixation, phosphate solubilization and IAA production, (iii) the genetic diversity of endophytes isolated from rice plant was evaluated in order to identify an efficient growth promotion strains that can be also improve the growth of rice plant as biofertilizer.

\section{Material and Methods}

\subsection{Sample Collection and Isolation of Endophytes}

Plant samples (Oryza sativa L.) were collected from in many sites in $\mathrm{Phu}$ Yen province (as a district in province)(Figure 1) from $12^{\circ} 42^{\prime} 36^{\prime \prime}$ to $13^{\circ} 41 ' 28^{\prime \prime} \mathrm{N}$ and from $108^{\circ} 40^{\prime} 40^{\prime \prime}$ to $109^{\circ} 27^{\prime} 47^{\prime \prime}$ E. Samples were obtained whole plant after that soil rhizosphere was separated for

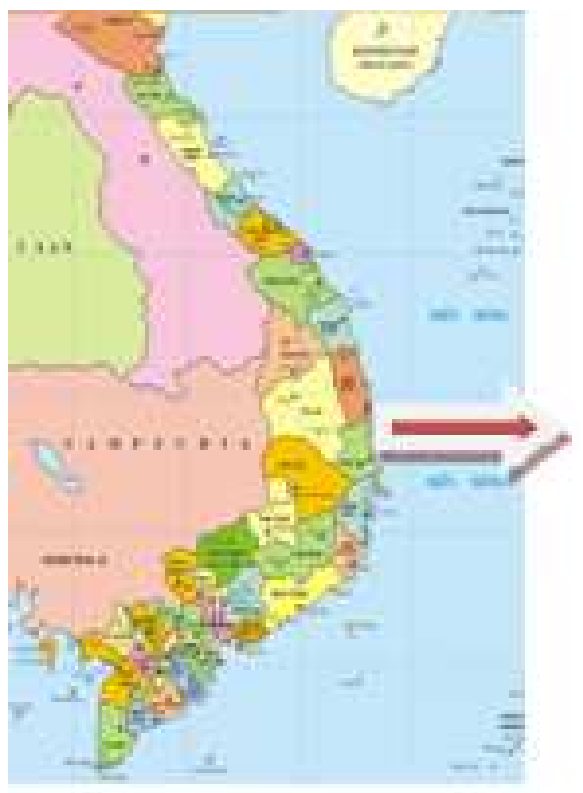

further experiments, rice roots were washed with tap water to remove attached clay; Rice stem and root were cut separately. Subsequently, the stem and roots were immersed in $70 \%$ ethanol in $3 \mathrm{~min}$, washed with fresh sodium hypochlorite solution $\left(2.5 \%\right.$ available $\left.\mathrm{Cl}^{-}\right)$for $5 \mathrm{~min}$, rinsed with hydrogen peroxide (3\%) for $30 \mathrm{~s}$ and finally washed five times with sterile distilled water. To confirm that the sterilization process was successful, the aliquots of the sterile distilled water used in the final rinse were set on tryptone - yeast extract - glucose agar medium plates. The plates were examined for bacterial growth after incubation at $28^{\circ} \mathrm{C}$ for 3 days. Rice stem and roots samples that were not contaminated as detected by culture-dependent sterility test were used for further analysis. Samples (stem or root) were cut to $1-2 \mathrm{~cm}$ pieces and macerated with a sterile mortar and pestle; tissue extracts were then serially (tenfold dilution) in sterile water, $200 \mu$ l-aliquot samples were used to inoculate in (in triplicate) Nitrogen-free semisolid LGI, $\mathrm{NFb}$ and RMR in $5 \mathrm{ml}$ tubes. After $48-72 \mathrm{~h}$ incubation, bacteria growing in tubes as a white or yellow pellicle at a depth of 1 to $4 \mathrm{~mm}$ were streaked on LGI, NFb and RMR agar plates, cultures were streaked on media to obtain single colonies.

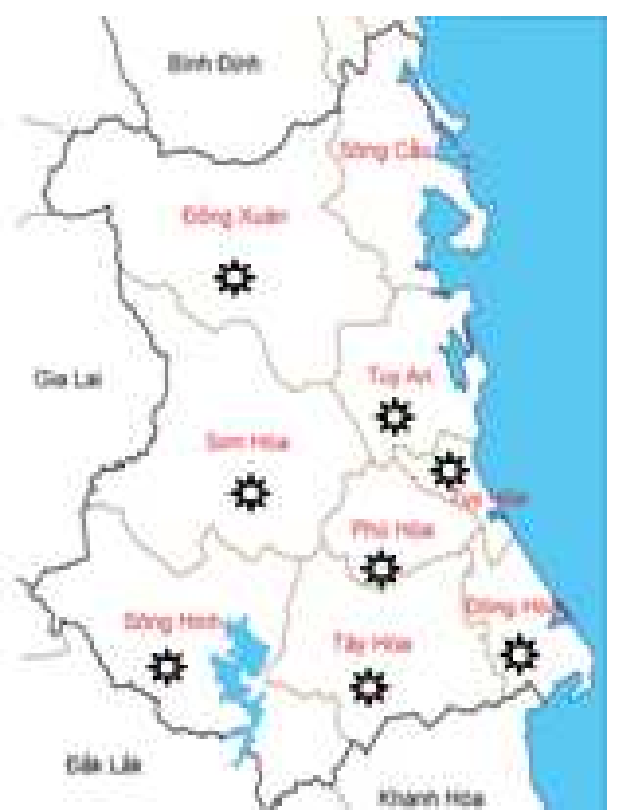

Figure 1. The geographic map and location of Phu Yen province, Vietnam examined in this study (coastal province of Central Vietnam)and rice samples were collected at the these sites

Bacterial colonies were differentiated on the basis of colony morphology and pigmentation. Colonies were subculture on the agar-based subculture medium plates by striking technique and re-incubated at $30^{\circ} \mathrm{C}$ for 4 days. This isolation process carries out in shifts of the agar-based culture medium to the agar-based subculture medium until monocultures were obtained. Monocultures were culture on the agar-based culture medium slant in the test-tube $(12 \mathrm{ml})$ and incubated at $30^{\circ} \mathrm{C}$ for 4 days following by stored $4^{0} \mathrm{C}$ in refrigerator.

\subsection{Culture Media and Growth Conditions}

Isolation media were LGI [9], NFb [10], RMR [11]; for biofertility activities were Burk'N free [12], NBRIP [13].

\subsection{Colony Characteristic and Microscopic Examination}

The characteristics of colony such as size, color, shape....were presented in each group, cell morphologies of the isolates were observed using an optical microscope and they were also observed on scanning electron microscope. 


\subsection{Screening for Biofertilizer Activities}

The ability to fix $\mathrm{N}_{2}$ was tested on Burk' $\mathrm{N}$-free liquid medium incubating at $30^{\circ} \mathrm{C}$ and the ammonium concentration in medium was measured by Phenol Nitroprusside method after 2,4,6 and 8 day inoculation (DAI) and inorganic phosphate solubilization ability was tested on NBRIP liquid medium and they were incubated at $30^{\circ} \mathrm{C}$ and the $\mathrm{P}_{2} \mathrm{O}_{5}$ concentration was measured by ammonium molypdate method after 5,10,15 and 20 day inoculation (DAI). The qualitative detection of indole-3-acetic acid (IAA) production was carried out based on the colorimetric method [14]. Precultures were grown in Burk's N free (100 $\mathrm{ml})$ with $100 \mathrm{mg} / 1$ tryptophan in $250 \mathrm{~mL}$-flask at $30^{\circ} \mathrm{C}$ on a roller at $100 \mathrm{rpm}$ and samples were taken from at 2, 4, 6, and 8 DAI, cell free supernatants were mixed 2:1 with Salkowki reagent $\left(0.01 \mathrm{M} \mathrm{FeCl}_{3}\right.$ in $35 \%$ perchloric acid $)$ and incubated in the dark for $20 \mathrm{~min}$ at RT. IAA-containing solutions were indicated by reddish color with an absorption peak at $530 \mathrm{~nm}$ on Genesys 10uv Thermo Scientific spectrophotometer.

\subsection{S rDNA Gene Amplification and Sequencing}

Bacterial DNA was isolated following published protocols [15]; The following primers were used for PCR amplification of $16 \mathrm{~S}$ ribosomal DNA: p515FPL [16] and p13B [17] [18]. The $50 \mu \mathrm{L}$ reaction mixture consisted of 2.5 U Taq Polymerase (Fermentas), $0.1 \mathrm{mM}$ of each desoxynecleotide triphosphate, $1.5 \mathrm{mM}$ magnesium chloride, $0.4 \mathrm{mM}$ spermidine (Sigma), $10 \mathrm{pM}$ of each primer (Fermentas) and $10 \mathrm{ng}$ DNA, 10\% (vol/vol) dimethyl disulfide (Fermentas). The thermocycling profide was carried out with an initial denaturation at $94^{\circ} \mathrm{C}$ (3 min) followed by 30 cycles of denaturation at $94^{\circ} \mathrm{C}(60 \mathrm{~s})$, annealing at $57^{\circ} \mathrm{C}(60 \mathrm{~s})$, extension at $72^{\circ} \mathrm{C}(120 \mathrm{~s})$ and a final extension at $72^{\circ} \mathrm{C}(4 \mathrm{~min})$ in $\mathrm{C} 1000$ Thermal Cycler (Bio-Rad). Aliquots $(10 \mu \mathrm{l})$ of PCR products were electrophoresed and visualized in $1 \%$ agarose gels using standard electrophoresis procedures. Partial 16S rRNA gene of selectived isolates in each site was sequenced by MACROGEN, Republic of Korea (dna.macrogen.com). Finally, 16S rRNA sequence of the isolate was compared with that of other microorganisms by way BLAST (http://www.ncbi.nlm.nih.gov/BLAST/Blast.cgi); In the best isolate(s)(high ability of nitrogen fixation, phosphate solubilization and IAA synthesis) and 73 isolates of 8 sites were chosen to sequence and the results were compared to sequences of GenBank based on partial 16S rRNA sequences to show relationships between endophytic strains [19] and phylogenetic tree were constructed by the neighbor-joining method using the MEGA software version 6.06 based on 1000 bootstraps.

\subsection{PCR Amplification of the nif-H Genes}

PCR amplification was performed to determine the presence of nif-H gene using specific primers described by
Poly et al. [20]. Amplification reaction was performed in a total volume of $25 \mu \mathrm{l}$. The reaction mixture contained: $2.5 \mu \mathrm{l}$ 10x PCR buffer, $2.5 \mu \mathrm{l}$ of $2 \mathrm{mM}$ each of dATP, dCTP, dTTP and dGTP, $3 \mu \mathrm{l}$ of each forward PolF (5'-TGCGYCCSAARGCBGACTC-3') and reverse PolR (5'-ATSGCCATYTCRCCGGA-3') primer (30 ng), $1 \mu \mathrm{l}$ of template DNA (10 ng) and $0.3 \mu \mathrm{l}$ of (3 U/1) Taq polymerase; final volume was made into $25 \mu \mathrm{l}$ using mili-Q water. The step-up PCR procedure included denaturation at $95^{\circ} \mathrm{C}$ for 3 min, $58^{\circ} \mathrm{C}$ for $1 \mathrm{~min}$, and $72^{\circ} \mathrm{C}$ for $1 \mathrm{~min}$, followed by 35 cycles of $95^{\circ} \mathrm{C}$ for $45 \mathrm{sec}, 58^{\circ} \mathrm{C}$ for $45 \mathrm{sec}$, and $72^{\circ} \mathrm{C}$ for 1 min, with a final extension at $72^{\circ} \mathrm{C}$ for $7 \mathrm{~min}$. Amplication products were electrophoreses on $1.5 \%$ agarose gel in $1 \mathrm{X}$ Tris-borate-EDTA (TBE) buffer.

\subsection{SNPs Discovery}

The sequence date from 73 root-associated bacterial isolates were analysed with SeqScape@Software (Applied Biosystem, Foster City, CA, USA). SeqScape is a sequence comparison tool for variant identification, SNP discovery and validation. It considers alignment depth, the base calls in each of the sequences and the associated base quality values. Putative SNPs were accepted as true sequence variants if the quality value exceeded 20 . It means a $1 \%$ chance basecall is incorrect.

\subsection{Nucleatide Diversity ( $(\theta)$}

Nucleotide diversity $(\Theta)$ was calculated by the method described by Halushka et al. [21]

$$
\Theta=\mathrm{K} / \mathrm{aL} \quad \mathrm{a}=\sum_{i=2}^{n} 1 /(i-1)
$$

where $\mathrm{K}$ is the number of SNPs identified in an alignment length, $\mathrm{n}$ is alleles and $\mathrm{L}$ is the total length of sequence (bp).

\subsection{Data Analyses}

Data from ammonium, orthophosphate and IAA concentrations in media were analysed in completely randomized design with three replicates and LSD test at $\mathrm{P}=0.01$ were used to differentiate between statistically different means using Minitab version 16.

\section{Results and Discussion}

\subsection{Bacteria Isolation, Colony Characteristic and Microscopic Examination}

The endophyte bacteria developed in the pelicles of semi solid (in three kinds of medium) as the previous results of Thu Ha et al. [22]. From 70 rice samples of 8 sites, 561 isolates were isolated on three kinds of medium (Table 1). 
120 Van Thi Phuong Nhu and Cao Ngoc Diep: Isolation, Charcaterization and Phylogenetic Analysis of Endophytic Bacteria in Rice Plant Cultivated on Soil of Phu Yen Province, Vietnam

Table 1. Total of isolates were isolated from 8 sites in Phu Yen province, Vietnam

\begin{tabular}{lcccc}
\hline Site & $\begin{array}{c}\text { Isolate number were isolated } \\
\text { from LGI medium }\end{array}$ & $\begin{array}{c}\text { Isolate number were isolated } \\
\text { from NFb medium }\end{array}$ & $\begin{array}{c}\text { Isolate number were isolated } \\
\text { from RMR medium }\end{array}$ & Total \\
\hline Tuy An & 46 & 58 & 47 & 151 \\
Son Hòa & 20 & 30 & 26 & 76 \\
Dong Xuan & 10 & 19 & 16 & 45 \\
Phu Hoa & 22 & 25 & 18 & 75 \\
Tay Hoa & 25 & 20 & 9 & 63 \\
Song Hinh & 11 & 9 & 15 & 29 \\
Đong Hoa & 10 & 18 & 31 & 43 \\
Tuy Hoa town & 20 & 28 & 9 \\
\hline
\end{tabular}

They developed very well on these media from $36-48 \mathrm{~h}$ at $30^{\circ} \mathrm{C}$, their colonies had round-shape, climy, smooth, colourless or milk-color, yellow and some colonies appeared to have much larger size (Figure 2).
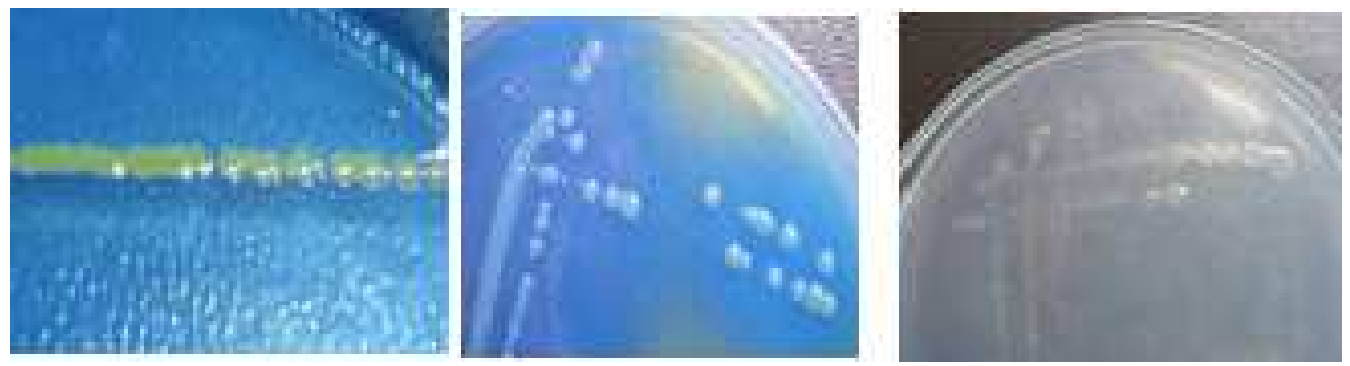

Figure 2. Characteristics of colonies of bacterial isolates after grown on three kinds of medium.

Microscopic observations showed that the cells of bacterial isolates were motile, rod, Gram-positive and

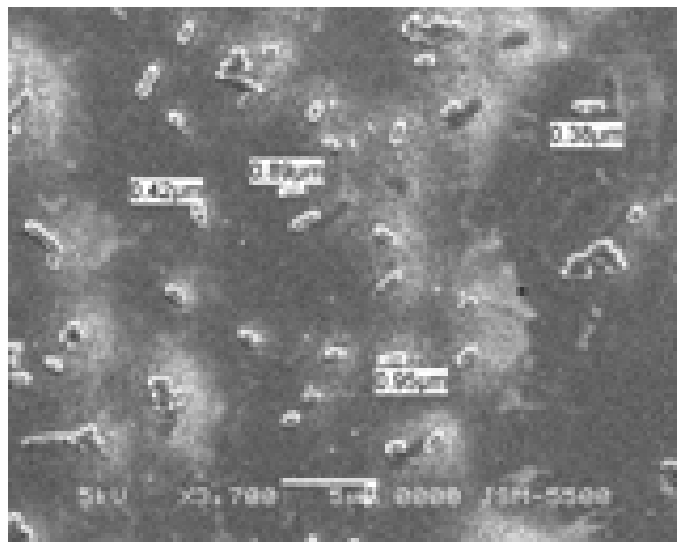

Gram-negative (Figure 3), short-rods $(0.38 \times 0.89 \mu \mathrm{m})$ and long-rods $(0.48 \times 1.22 \mu \mathrm{m})$.

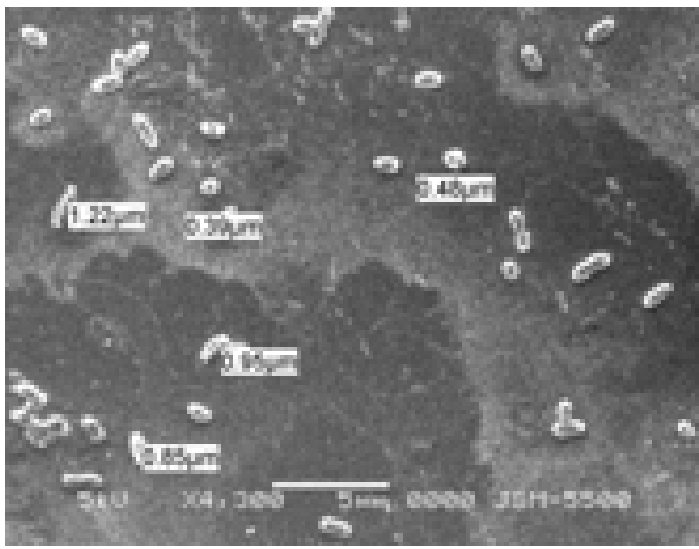

Figure 3. Electron microghaphs (bars, $5 \mu \mathrm{m}$ ) of cells of bacterial isolates grown on three kinds of medium 


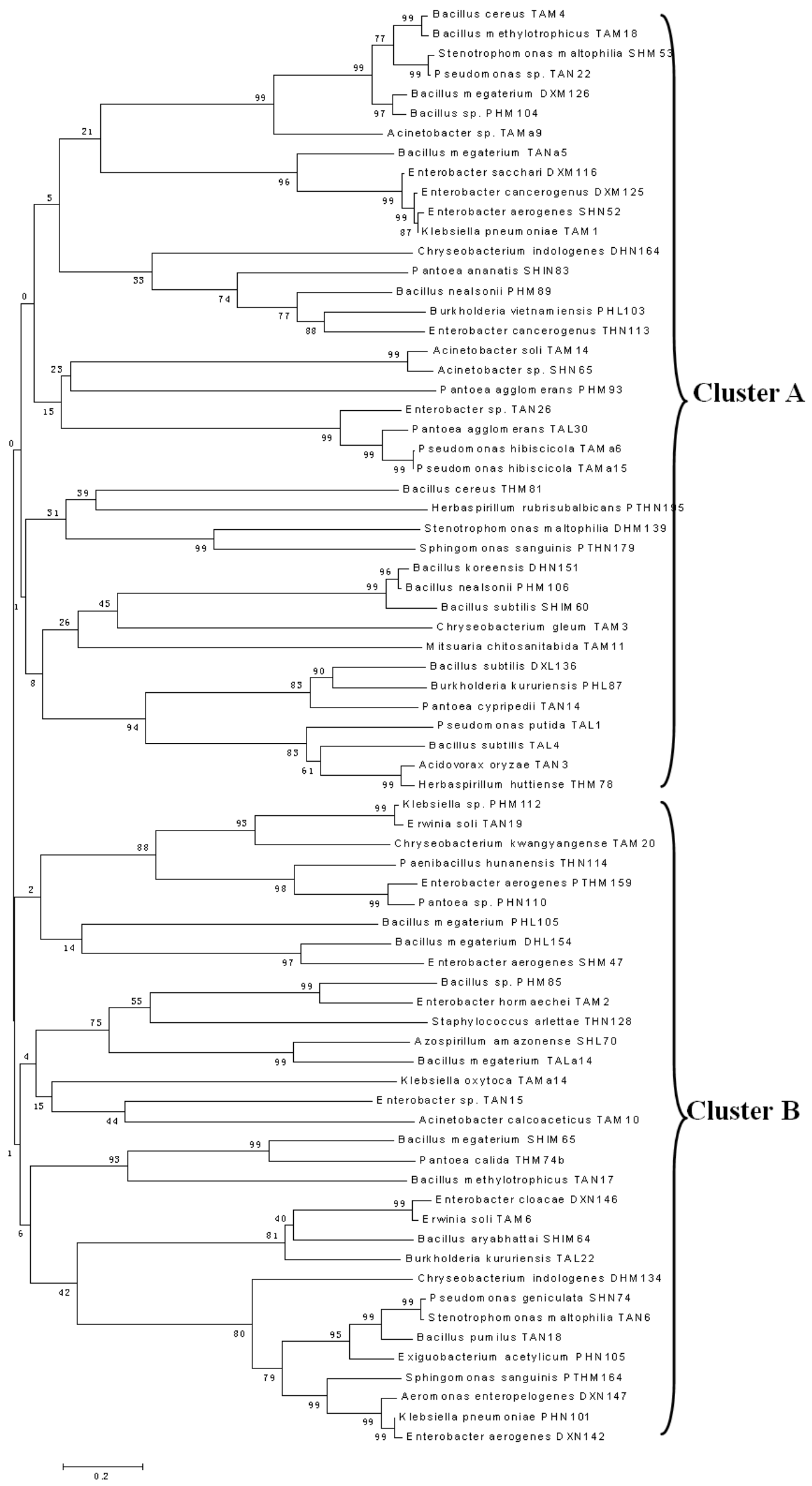

Figure 4. Phylogenetic tree for partial $16 S$ rRNA gene sequences from 73 isolates by using primers (p515FPL, p13B) showing relationships between representative strains along with related sequences retrieved from GenBank. The numbers at the nods indicate the levels of bootstrap support (\%) based on a Neighbor-Joining analysis of 100 re-sampled datasets. The scale bar indicates the phylogenetic distance corresponding to 5 changes per 100 bases. 


\subsection{Screening for Biofertilizer Activities}

Among 561 isolate, 73 isolates having good biofertilizer activity were chosen to study (Table 2). All 73 isolates have nitrogen fixation, phosphate solubilization ability) and all of them produced indole-3-acetic acid (IAA) in vitro.

Several isolates have good plant growth activities as TANa5, TAN17, TALa14, TAL1, TAL4, TAL22, TAL30 (Tuy An), SHL70 (Son Hoa), DXL136 (Dong Xuan), PHL87, PHL103, PHL105 (Phu Hoa), SHIM60 (Song Hinh), DHL154 (Dong Hoa)(bold number in table 2). Endophytes increase plant growth through the improved cycling of nutrients and minerals such as nitrogen, phosphate and other nutrients [23]. Endophytes also promote plant growth by a number of similar mechanisms as phosphate solubilization activity [6], indole acetic acid production [7].

\subsection{S rDNA Gene Amplification, Sequencing and NIF-H Gene}

All of them (73 isolates) were chosen to identify and the fragments of $900 \mathrm{bp} 16 \mathrm{~S}$ rRNA were obtained from PCR and sequencing (Table 3), they are endophyte bacteria in rice.

The determination of nearest phylogenetic neighbor sequences for $16 \mathrm{~S}$ rRNA gene sequence of the 73 isolates by the BLAST search program showed that they grouped into two clusters (Figure 4). Cluster A consisted of the strains which originated from rice cultivating in high-land soil and cluster B included the strains which originated from rice in low-land soil; The low-land rice plantes during the year (2-3 cropping seasons) with drainage and the high-land rice only cultivates in wet-season (1 or 2 cropping-season(s)) when the rainy season however these groups did not separate Gram-positive or Gram-negative bacteria with the beneficial bacteria described for a long time [24][25][26] and they belonged to the class Bacilli (31.54\%), Gamma-Proteobacteria (49.31\%), Beta-Proteobacteria $(9.59 \%)$, Bacteroides $(8.22 \%)$ and Alpha-Proteobacteria $(1.34 \%)$ (Figure 5)

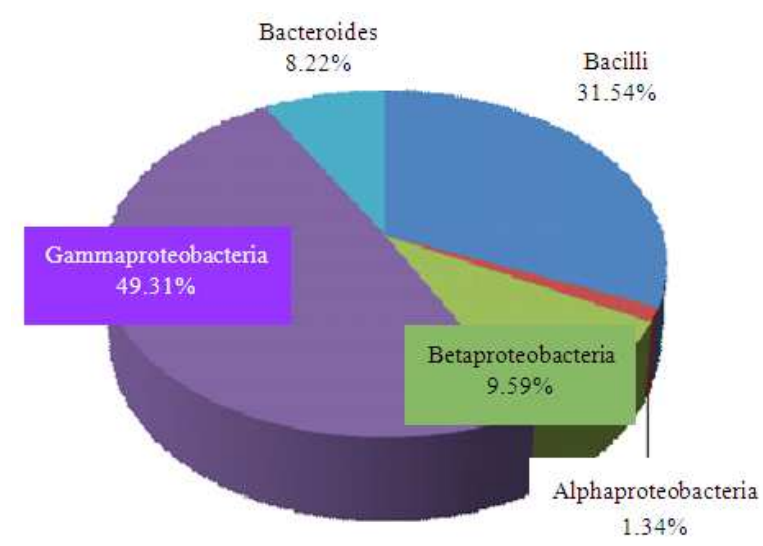

Figure 5. The proportion of group and they distributed in two clusters

Nucleotide polymorphism can be measured by many methods, for example, halotype (gene) diversity, nucleotide diversity, (Pi), The ta $(\Theta)$ (per group) etc... In this study, nucleotide diversity was estimated as Theta $(\Theta)$, the number of segregating sites [27], and its standard deviation (SE). These parameters were estimated by DNA Sequence Polymorphism software version 4.0 [28].

Pi value explained nucleotide diversity of sequences for each gene; the higher values, the more diversity among Bacteroides group had the highest values and Betaproteobacteria group had the lowest values. Theta values (per sequence) from $\mathrm{S}$ of SNP for DNA polymorphism were calculated for each group and Bacteroides group had the highest values in comparison of three groups (Table 4).

Table 4. Nucleotide diversity $(\theta)$ values of two EST's using the programme DNASp 4.0 [28]

\begin{tabular}{lcccc}
\hline ESTs & $\begin{array}{c}\text { Gamma } \\
\text { proteobac } \\
\text { teria }\end{array}$ & Bacilli & $\begin{array}{c}\text { Beta } \\
\text { proteobac } \\
\text { teria }\end{array}$ & $\begin{array}{c}\text { Bacteroid } \\
\text { es }\end{array}$ \\
\hline $\begin{array}{l}\text { Nucleotide } \\
\text { diversity (Pi) }\end{array}$ & 0.71778 & 0.71979 & 0.71637 & 0.73506 \\
$\begin{array}{l}\text { Theta (per } \\
\text { sequence) }\end{array}$ & $153.613 \pm$ & $169.339 \pm$ & $306.939 \pm$ & $355.182 \pm$ \\
from Eta & 37.044 & 45.881 & 125.281 & 155.554 \\
\hline
\end{tabular}

Primer p515FPL 5'-GTGCCAGCAGCCGCGTAA-3' Primer p13B 5'-AGGCCCGGGAACGTATTCAC-3'

Amplication of nifH gene: to confirm the potential for nitrogen fixation, the presence of the structural gene for nitrogenase reductase (nifH) was determined by nifH gene amplication with genomic DNA extracted from 73 strains representive strains belonged to 5 groups (Figure 6), Amplication with the gene specific primers yielded the expected 360-bp size product on agarose gel. This demonstrated these 73 strains are endophytes and nitrogen fixation ability or 73 diazotrophic endophytes in rice cultivated on soil of Phu Yen province, Vietnam.

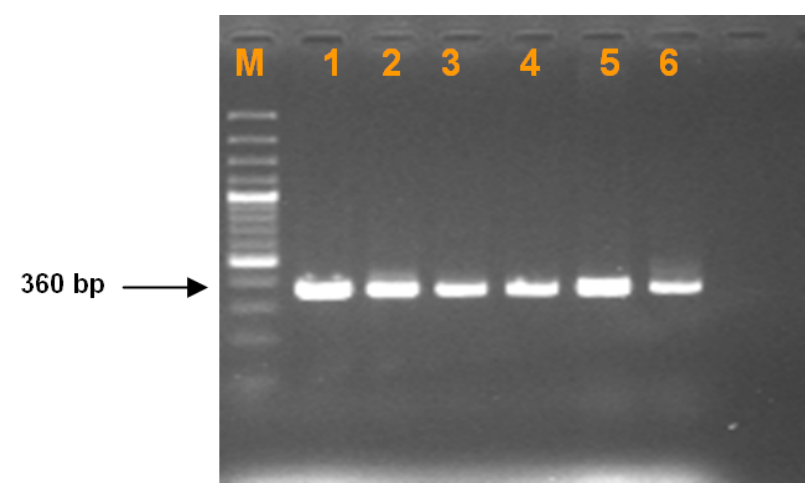

Figure 6. Agarose gel gel electrophoresis of PCR products obtained by amplifying nif-H gene from genomic DNA of bacterial isolates. $M$, marker 100bp DNA ladder, 1-6 were 6 strains among 73 strains.

Research on the bacteria residing in the internal tissues of plants began in the 1870s with Pasteur and others and Perotti was the first to describe the occurrence of a nonpathogenic flora in root tissues, and Hennig and Villforth reported the 
presence of bacteria in the leaves, stems, and roots of 28 apparently healthy plants. Since 1940, there have been numerous reports on indigenous endophytic bacteria in various plants tissues [29]. In the 1980s, endophytic bacteria having nitrogen-fixing activity were found in gramineous plants [30][31]. Diversity associated with bacteria endophytes exists, not only in the plant species colonized but also in the colonizing bacterial taxa. The variation in bacteria that has been reported as endophytes spans a significant range of Gram-positive and Gram-negative bacteria and includes more than 80 genera and the members of the group of the pink-pigmented facultively methylotrophic bacteria such as Methylobacterium [32]. Prakamhang et al. [33] applied Pol primers to detect nifH gene of endophytic diazotrophic bacteria in cultivated rice in
Thailand and they could detect the expression of this gene in different parts and growth stages of rice plants, our results only detected nifH gene in bacteria in laboratory condition but cultivated rice applied high amount of chemical nitrogen, the nifH gene indicated lower diversity in plant grown in soil fertilized according to local custom $\left(35.9 \mathrm{mg} \mathrm{kg}^{-1}\right)$ [33], this results showed that high inorganic nitrogen in soil will limit the expressive of nifH gene. From 2005, we discovered endophytic bacteria in wild rice (Oryza sp.) in the Mekong Delta, Vietnam [34] and Azospirillum lipoferum was detected as endophyte in local rice cultivars in the Mekong Delta, Vietnam [35][36] and nifH gene was identified in Pseudomonas stutzeri (isolates from rice rhizosphere soil in the Mekong Delta, Vietnam)[37] and its has been used as bio-fertilizer on rice cultivation effectively [38][39][40][41].

Table 2. Nitrogen fixation, phosphate solubilization and IAA synthesis production of 73 isolates

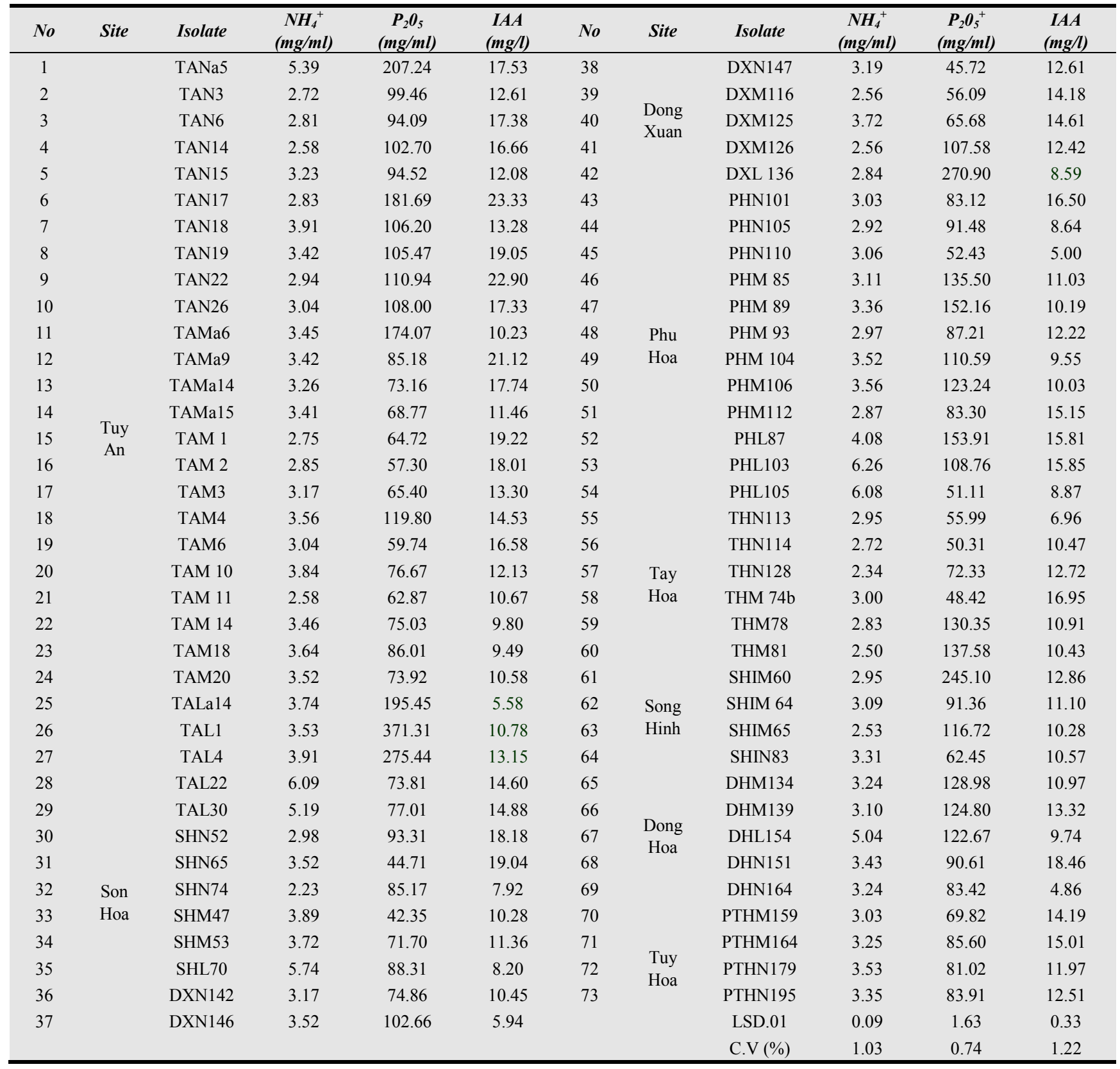


124 Van Thi Phuong Nhu and Cao Ngoc Diep: Isolation, Charcaterization and Phylogenetic Analysis of Endophytic Bacteria in Rice Plant Cultivated on Soil of Phu Yen Province, Vietnam

Table 3. Phylogenetic affiliation of isolates on the basis of $16 \mathrm{~S}$ rDNA gene sequences by using BLAST programme in the GenBank database based on sequence similarity

\begin{tabular}{|c|c|c|}
\hline Taxonomic group and strain & Closest species relative & Similarity (\%) \\
\hline \multicolumn{3}{|l|}{ Bacilli } \\
\hline TALa14 & Bacillus megaterium strain p16_B11 (JQ833394) & 99 \\
\hline PHL105 & Bacillus megaterium strain p19_A07 (JQ834169) & 99 \\
\hline DHL154 & Bacillus megaterium strain IARI-K-86 (JN411367) & 99 \\
\hline TANa5 & Bacillus megaterium strain Y18-04 (GU143908) & 98 \\
\hline SHIM65 & Bacillus megaterium strain GC61 (KF158230) & 99 \\
\hline DXM126 & Bacillus megaterium strain ACCC11011 (KC768806) & 99 \\
\hline TAL4 & Bacillus subtilis strain V90 (HQ268534) & 99 \\
\hline DXL136 & Bacillus subtilis strain Gr5 & 99 \\
\hline THM60 & Bacillus subtilis strain M18SP4Q(ii) (KC886741) & 99 \\
\hline TAM18 & Bacillus methylotrophicus strain VSD607 (KC534272) & 99 \\
\hline TAN17 & Bacillus methylotrophicus strain LZ023 (JQ023616) & 99 \\
\hline DHN151 & Bacillus koreensis strain TSI-2 (JN993703) & 99 \\
\hline TAM4 & Bacillus cereus strain SCD10 (KF476040) & 99 \\
\hline THM81 & Bacillus cereus strain p28_F07 (JQ835716) & 97 \\
\hline PHM106 & Bacillus nealsonii strain BAB-2836 (KF535131) & 99 \\
\hline PHM89 & Bacillus nealsonii strain EkC3-4 (KF032671) & 99 \\
\hline SHIM64 & Bacillus aryabhattai strain YN24 (KC511542) & 99 \\
\hline TAN18 & Bacillus pumilus strain vit bac1 (KC845305) & 98 \\
\hline PHM104 & Bacillus sp. Y19(2013) (KC708569) & 99 \\
\hline PHM85 & Bacillus sp. B-23286 (AF169504) & 99 \\
\hline THN114 & Paenibacillus hunanensis strain Fek21 (EU741031) & 98 \\
\hline THN128 & Staphylococcus arlettae strain IHB B 8022 (KF475813) & 97 \\
\hline PHN105 & Exiguobacterium acetylicum strain PNS-30 (JQ218452) & 99 \\
\hline \multicolumn{3}{|l|}{ Alphaproteobacteria } \\
\hline SHL70 & Azospirillum amazonense strain LMG 22237 (KC109787) & 98 \\
\hline \multicolumn{3}{|l|}{ Betaproteobacteria } \\
\hline TAN3 & Acidovorax oryzae strain YNA110 (JN700196) & 99 \\
\hline PTHN195 & Herbaspirillum rubrisubalbicans strain PPs-3 (FJ605419) & 99 \\
\hline THM78 & Herbaspirillum huttiense, strain: NBRC 102521 (AB681855) & 99 \\
\hline TAL22 & Burkholderia kururiensis strain LUC24 (AY586518) & 100 \\
\hline PHL87 & Burkholderia kururiensis strain PR1（JX083379) & 99 \\
\hline PHL103 & Burkholderia vietnamiensis strain RPB3 (HQ606073) & 99 \\
\hline TAM11 & Mitsuaria chitosanitabida strain R8-376 (JQ659937) & 97 \\
\hline \multicolumn{3}{|l|}{ Gammaproteobacteria } \\
\hline TAM14 & Acinetobacter soli strain MBR4 (JX966422) & 99 \\
\hline TAM10 & Acinetobacter calcoaceticus strain B40 (JX010982) & 98 \\
\hline SHN65 & Acinetobacter sp. U1369-101122-SW178-2 (JQ082154) & 97 \\
\hline TAMa9 & Acinetobacter sp. $1064 \quad$ (KC236451) & 99 \\
\hline SHIN83 & Pantoea ananatis strain 3Pe76 (EF178449) & 99 \\
\hline TAN14 & Pantoea cypripedii strain Dc-08 (KC153127) & 99 \\
\hline PHM93 & Pantoea agglomerans strain T224 (KC764985) & 99 \\
\hline THM74b & Pantoea calida strain 1400/07 (GQ367478) & 99 \\
\hline TAL30 & Pantoea agglomerans strain BJCP3 (HM130694) & 99 \\
\hline PHN110 & Pantoea sp. B2011 (JX266366) & 98 \\
\hline SHN74 & Pseudomonas geniculata strain JS3 ( JX042459) & 99 \\
\hline
\end{tabular}




\begin{tabular}{|c|c|c|}
\hline Taxonomic group and strain & Closest species relative & Similarity (\%) \\
\hline TAL1 & Pseudomonas putida strain C-S-TSA6 (HM755575) & 99 \\
\hline TAMa15 & Pseudomonas hibiscicola strain R4-722 (JQ659712) & 99 \\
\hline TAMa6 & Pseudomonas hibiscicola strain R4-790 (JQ659719) & 98 \\
\hline TAN22 & Pseudomonas sp. ZR3 (JQ433923) & 99 \\
\hline PHN101 & Klebsiella pneumoniae strain R3 (KC990817) & 99 \\
\hline TAM1 & Klebsiella pneumoniae strain U6 (KC434997) & 98 \\
\hline TAMa14 & Klebsiella oxytoca strain AIMST 10.Pl.3 (HQ683968) & 99 \\
\hline PHM112 & Klebsiella sp. A712 (JF946802) & 99 \\
\hline DXN146 & Enterobacter cloacae strain GAQ39 (JX827464) & 99 \\
\hline DXM125 & Enterobacter cancerogenus strain 46 (C2P1) (KF254599) & 99 \\
\hline THN113 & Enterobacter cancerogenus, strain: NMB8-2 (AB776824) & 99 \\
\hline SHM47 & Enterobacter aerogenes strain p62_A05 (JQ829356) & 99 \\
\hline DXN142 & Enterobacter aerogenes strain gx-32 (FJ823005) & 99 \\
\hline PTHM159 & Enterobacter aerogenes strain gx-32 (FJ823005) & 99 \\
\hline SHN52 & Enterobacter aerogenes strain DCH-2 $\quad(\mathrm{KC} 166865)$ & 99 \\
\hline TAM2 & Enterobacter hormaechei strain RB12 (KC431790) & 99 \\
\hline DXM116 & Enterobacter sacchari strain SP1 (JQ001784) & 99 \\
\hline TAN15 & Enterobacter sp. YR2-2 (JQ229706) & 98 \\
\hline TAN26 & Enterobacter sp. isolate CCM6B (FN433019) & 99 \\
\hline DHM139 & Stenotrophomonas maltophilia strain L1 (KF358247) & 99 \\
\hline SHM53 & Stenotrophomonas maltophilia strain TWNG12 (KF312295) & 99 \\
\hline TAN6 & Stenotrophomonas maltophilia strain G8 (KC136825) & 99 \\
\hline TAM6 & Erwinia soli strain AR_PINLTS1 (HM582880) & 99 \\
\hline TAN19 & Erwinia soli strain AR_PINLTS1 (HM582880) & 98 \\
\hline DXN147 & Aeromonas enteropelogenes strain RS113 (KC122705) & 98 \\
\hline \multicolumn{3}{|l|}{ Bacteroidetes } \\
\hline PTHN179 & Sphingomonas sanguinis strain L3-149 (JQ659330) & 98 \\
\hline PTHM164 & Sphingomonas sanguinis strain L3-149 (JQ659330) & 99 \\
\hline DHN164 & Chryseobacterium indologenes strain N6 (KC189901) & 99 \\
\hline TAM3 & Chryseobacterium gleum strain AOLR31 (GQ916521) & 98 \\
\hline TAM20 & Chryseobacterium kwangyangense strain Cb (EU169201) & 99 \\
\hline DHM134 & Chryseobacterium indologenes strain ZYF120413-7 (KF017580) & 99 \\
\hline
\end{tabular}

\section{Conclusions}

From 70 cultivated rice samples on low fertility of soil in Phu Yen province, a province in coastal region of Central Vietnam, 561 isolates were isolated and identified as rice endophytes and 73 isolates having good plant growth promotion from 8 sites $(8$ districts in province) were chosen to analyse their relationship and they showed that bacterial diversity was very high and $13 / 73$ strains will be suggested to produce bio-fertilizer for rice cultivation this region in the future.

\section{Acknowledgements}

The authors thank the helpness of Microbiology BSc. Students and technicians in the Environment Microbiology Laboratory, Biotechnology R\&D Institute, Can Tho University, Vietnam, especially Associate Professor Dr. TRUONG TRONG NGON, Head of Molecular Biology
Department, Biotechnology R\&D Institute, Can Tho University, Vietnam analysed data and nucleotide diversity.

\section{References}

[1] IRRI, AfricaRice, CIAT, "Global Rice Science Partnership (GRiSP), November, 2010.

[2] P.A. Seck, A. Diagne, S. Mohanty and M.C.S. Wopereis, "Crops that feed the world 7:rice," Food Sec., vol. 4, pp. 7-24, 2012.

[3] P. Gyaneshwar, E.K. James, N. Mathan, P.M. Reddy, B. Reinhold-Hurek, J.K. Ladha, "Endophytic colonization of rice by a diazotrophic strain of Serratia marcescens," J. Biotechnol., vol. 183, pp.2634-2645, 2001.

[4] J.K. Ladha and P.M. Reddy, "Nitrogen fixation in rice ecosystem: state of knowledge and futrure prospects," Plant Soil, vol. 252, pp.151-167, 2003. 
[5] R.M. Boddey, .C. de Oliveira, S. Urquiaga, V.M. Reis, F.L. de Olivares, V.L.D. Baldani, and J. Dobereiner, "Biological nitrogen fixation associated with sugarcane and rice: Contributions and Prospects for improvement," Plant Soil, vol.174, pp.195-209, 2005.

[6] S, Wakelin, R. Warren, P. Harvey and M. Ryder, "Phosphate solubilization by Penicillium spp. closely associated with wheat roots," Bio. Fert. Soils, vol. 40, pp.36-43, 2004.

[7] S. Lee, M. Flores-Encarnation, M. Contreras-Zentella, L. Garcia-Flores, J.E. Escamilla and C. Kennedy, "Indole-3-acetic acid biosynthesis is deficient in Gluconacetobacter diazotrophicus strains with mutations in cychrome C biogenesis genes," J. Bacteriol., vol. 186, pp.5384-5391, 2004.

[8] J.M. Costa and J.E. Loper, "Characterization of siderophore production by the biological-control agent Enterobacter clocae," Mol. Plant Microbe. Interact., vol.7, pp.440-448, 1994.

[9] V.A. Cavalcante and J. Dobereiner, "A new acid tolerant nitrogen fixing bacterium associated with sugarcane," Plant Soil, vol. 108, pp.23-31, 1988.

[10] G. Kirchhof, V.M. Reis, J.J. Baldani, B. Eckert, J. Dobereiner, and A. Hartmann, "Occurrence, physiological and molecular analysis of endophytic diazotrophic bacteria in gramineous energy plants," Plant Soil, vol. 194, pp.45-55, 1997.

[11] A. Elbeltagy, K. Nishioka, T. Sato, H. Suzuki, B.Ye, T. Hamada, T. Isawa, H. Mitsui and K. Minamisawa, "Endophytic colonization and in planta nitrogen fixation by a Herbaspirillum sp. isolation from wide rice species," Appl. Environ. Microbiol., vol.38, pp. 5285-5293, 2001.

[12] M. Park, C. Kim, J. Yang, H. Lee, W. Shin, S. Kim and T. Sa, "Isolation and characterization of diazotrophic growth promoting bacteria from Gram rhizosphere of agricultural crops of Korea," Microbiological Research, vol. 160, pp. $127-133,2005$

[13] C.S. Nautiyal, "An efficient microbiological growth medium for screening phosphate-solubilizing microorganisms," FEMS Microbiology Letters, vol. 170, pp.256-270, 1999.

[14] S.A. Gordon and R.P. Weber., "Colometric estimation of indolacetic acid," Plant Physiol., vol 26, pp.192-195, 1951.

[15] B. Neumann, A. Pospiech, and H.U. Schairrer, "Rapid isolation of genomic DNA from Gram-negative," Trends Gent., vol. 8, pp. 332-333, 1992.

[16] D.A. Relman, T.M. Schmidt, E.P. MacDermontt, and S. Falkow, "Identification of the uncultured bacillus of Whipple's disease,” N. Engl. J. Med., vol. 327, pp.293-301, 1992.

[17] D.A. Relman, J.S. Loutit, T.M. Schmidt, S. Falkow, and L.S. Tompkin, "The agent of bacillary angiomatosis. An approach to the identification of uncultuted pathogens," N. Engl. J. Med., vol. 323, pp.1573-1580, 1990.

[18] K.D. Zinniel, P. Lambercht, N.B. Harris, Z. Feng, D. Kuczmarshki, P. Higley, C.A. Ishimaru, A. Arunakumari, R.G. Barletta, and A.K. Vidaver, "Isolation and charcaterization of endophytic bacteria from agronomic crops and prairie plants,” Appl. Environ. Microbiol., vol. 68, pp. 2198-2208, 2002.
[19] K. Tamura, D. Peterson, N. Peterson, G. Stecher, M. Nei, and S. Kumar, "MEGA5: Molecular Evolutionary Genetics Analysis using Maximum Likehood, Evolutionary Distance and Maximum Parsimony Methods," Mol. Biol. Evol., vol. 28, pp. 2731-2739, 2011.

[20] F. Poly, L.M. Joteur, R. Bally, "Improvement in RELP procedure to study the community of nitrogen fixers in soil through the diversity of nifH gene." Res. Microbiol., vol. 152 pp. 95-103, 2001.

[21] M.K. Halushka, J.B. Fan, K. Bentley, L. Hsie, N. Shen, A. Weder, R. Cooper, R. Lipshutz, and A. Charavarti, "Patterns of single-nucleotide polymorphisms in candidate genes for blood-pressure homestasis," Nat. Genet., vol. 22(3), pp. 239-247, 1999

[22] N. T. Thu Ha, H. T. Toan, and C. N. Diep, "Isolation and characrterization of endophytic bacteria in several forage grass cultivars," J. Biotechnology., vol. 7(2), pp.241-250, 2009.

[23] R.P. Ryan, K. Germanie, A. Franks, D. J. Ryan and D.N. Dowling, "Bacterial endophytes: recent developments and applications," FEMS Microbiol. Lett., vol. 278, pp.1-9, 2008.

[24] H. Mano, F. Tanaka, A. Watanabe, H. Kaga, S. Okunishi, and H. Morisaki, "Culturable surface and endophytic bacteria flora of the manuring seeds of rice seeds of rice plants (Oryza sativa) cultivated in a paddy field," Microbes Environ., vol. 21, pp.86-100, 2006

[25] C. Koomnok, N. Teaumroong, B. Rerkasem, and S. Lumyong, "Diazotroph Endophytic Bacteria in Cultivated and Wild Rice in Thailand," ScienceAsia, vol.33, pp. 429-435, 2007.

[26] H. Mano and H. Morisaki, "Endophytic Bacteria in the Rice Plant," (minireview) Microbes Environ. vol. 23, pp.109-117, 2008.

[27] G.A. Watterson, "On the number of segregation sites in general models without recobination," Theor. Pop. Biol., vol. 7, pp. 256-276, 1975.

[28] J. Rozas, and R. Rozas, "DnaSP version 4.1: an integrated program for molecular population genetics and molecular evolution analysis," Bioinformatics, vol. 15, pp. 174-175, 2005.

[29] J. Hallmann, A. Quadt-Hallmann, W.F. Mahaffee, and J.W. Kleopper, "Bacterial endophytes in agricultural crops," Can. J. Microbiol., vol.43, pp.895-914, 1997.

[30] F.L. Olivares, V.L.D. Baldani, V.M. Reis, J.I. Baldani and J. Dobereiner, " Occurrence of the endophytic diazotrophs Herbaspirillum spp. in roots, stems, and leaves, predominantly of Gremineae," Biol. Fertil. Soils, vol. 21, pp.197-200, 1996.

[31] B. Reinhold-Hurek and T. Hurek, "Life in grasses: diazotrophic endophytes," Trend Microbiol., vol. 6, pp.139-144,1998.

[32] D.Y. Kobayashi and J.D. Palumbo, "Bacterial endophytes and their effects on plants and uses in agriculture," pp. 199-233, 2000. In: C.W. Bacon and J.F. White (ed.), Microbial Endophytes. Marcel Dekker, Inc, New York, N.Y.

[33] J. Prakamhang, K, Minamisawa, K. Teamtaisong and N, Boonkerg, "The communities of endophytic diazotrophic bacteria in cultivated rice (Oryza sativa L.,)," Applied Soil Ecology, vol. 42, pp.141-149, 2009. 
[34] C. N. Diep, L. K. Sau, and Q. V. Cao Thi, "Detection of diazotrophic endophytic bacteria in wild rice (Oryza sp.), "Proceedings of National Conference of Biology, Agriculture and Medicine organized at Medicine University of Ha Noi in 03 November, 2005, pp. 123-125. Science-Technology Publising House, Ha Noi, 2005.

[35] C. N. Diep, P. T. K. Van and L. N. Dau, "Detection of Endophytic Azospirillum lipoferum in local rice cultuvars (Oryza sativa L.) cultivated in the Mekong Delta, Vietnam. Proceedings of National Conference of Life Science organized at University of Qui Nhon, pp.456-459, Science-Technology Publising House, Ha Noi, 2007.

[36] L. N. Dau, N. T. X. My, and C. N. Diep, "Nitrogen fixation, Phosphate Solubilization and IAA biosynthesis of Endophytic Azospirillum lipoferum. Proceedings of National Conference of Life Science organized at University of Qui Nhon, pp.445-448, Science-Technology Publising House, Ha Noi, 2007.

[37] N. T. Phong and C. N. Diep, "Identification of nifH gene in Pseudomonas stutzeri isolated from rice rhizosphere soil in the Mekong Delta, Vietnam. J of Biotechnology, Vietnam
Academic Institute of Science and Technology, vol.9(4), pp.365-370, 2012.

[38] C. N. Diep, N. V. Mang, and L. T. Diem Ai, "Effects of nitrogen-fixing Azospirillum lipoferum and phosphate-solubilizing Pseudomonas stutzeri on high-yielding rice and soil fertility of Hau Giang province. J. Soil Science, vol. 34, pp.84-88, 2010.

[39] C. N. Diep,"Effect of biofertilizer on High-yielding Rice Cultivated on Alluvial Soil of Mekong Delta," Proceedings of JSPS AA International Seminar Can Tho University, Vietnam, September 2010, pp. 18-24. 2010.

[40] C. N. Diep and D. T. Dep, "Effect of DASVILA biofertilizer on high-yielding rice (cv. OM 2514) cultivated on alluvial soil of Song Hau farm, Can Tho city," Soil Science J., Viet nam, vol.36, pp.47-51, 2011.

[41] C. N. Diep and N. T. M. Tuyen,"Effect of DASVILA biofertilizer on high-yielding rice cultivated on alluvial soil of Tan Hiep district, Kien Giang province and Vinh Thanh district, Can Tho city," Soil Science J., Viet nam, vol.38, pp.91-94, 2011. 